\title{
Priority Sector Lending in India by Public and Private Sector Banks: A Comparative Analysis
}

\author{
Provinder Kumar* and Sanjeev Kumar**
}

\begin{abstract}
Priority sector lending is still and will continue to be an important focus and area of concern of all the commercial banks in the near future because of hard socio-economic realities of the Indian economy. The main objective of the paper is to analyse the level and structure of priority sector lending in India during the $21^{\text {st }}$ century. The entire study is based upon secondary data, collected from the various relevant issues published by RBI. The study is stretched over the period 2001 to 2014. With a view to analyse the growth of various components of priority sector lending, exponential growth rate has been calculated. The behaviour of inter-year disparities in priority sector lending is explained with the help of co-efficient of variation. The performance of public and private sector banks in priority sector lending has been compared with t-test. The study points out that, although, on an average, the prescribed target of priority sector lending has been achieved, but, one important issue of concern is the shrinking share of priority sector credit in net bank credit over a period of time by both the public and private sector banks, which needs immediate attention of the policy makers. The public and private sector banks could not deploy 18 per cent of net bank credit in agriculture sector and thus, failed to achieve the stipulated target of agricultural lending.
\end{abstract}

Keywords: Financial inclusion; Priority sector lending; Commercial banks; Exponential growth rate; Co-efficient of variation; Net Bank Credit (NBC).

\subsection{Introduction}

Banking is an important segment of the tertiary sector and acts as a backbone of economic progress. The banks render vital services to the masses belonging to various sectors of the economy like agriculture, industry: whether small scale or large scale.

*Research Scholar, Department of Commerce and Management, Career Point University, Kota, Rajasthan. (email: provinder78@gmail.com)

**Assistant Professor, Department of Economics, Govt. College Majheen, Distt. Kangra Himachal Pradesh. (email: drsanjeeveco0679@gmail.com) 
The banking system is one of the few institutions that impinge on the economy and affect its performance for better or worse. They act as a development agency and are the source of hope and inspiration to the masses.

A developing economy faces many problems, like poverty, scarcity of capital, lack of entrepreneurship etc. The commercial banks can work as catalytic agents of growth by following the right kind of policies in their working, depending upon the socio-economic conditions prevailing in the country. They have stupendous investment potential and can make a significant contribution in eradicating poverty, unemployment and in bringing about progressive reduction in inter-regional and inter-sectoral disparities through rapid expansion of banking services.

Priority sector occupies a special place in the Indian economy and is an important feature of the Indian banking policies. Priority sector lending is the crux of social banking. Under the priority sector lending, bank credit is provided on liberal terms and conditions. The socialisation of bank credit is the theme of priority sector lending by the commercial banks. Priority sector is and will continue to remain, the bread and butter, both literally and figuratively, of Indian economic growth. Since priority sector are critical to high and sustained growth of GDP, it should be the business of public sector banks to support these sectors. In 1980, a major review of the components of priority sector was undertaken by a working group headed by K.S. Krishnaswamy. The group recommended the incorporation of weaker sections, so that, the concessions that are being offered to the priority sector as a class could be oriented to meet the needs of the weaker sections. Credit was earmarked for the weaker sections of the society i.e. small and marginal farmer, landless labourers, SC/ST etc. to achieve this task banks opened more branches in rural areas which had no banking facilities.

Financial inclusion has become central to the Indian policy-making over the past few years and various attempts have been made to expand its scope. Despite these attempts, the challenges to financial inclusion remain formidable. These attempts and challenges have to be not only examined in the context of an increasingly globalised economy, of expanding markets, and of growing state intervention, but, also of local variations. Equally daunting is the magnitude of the task that requires regulating the activities of service providers to millions of illiterate and poor people spread among culturally disparate groups.

A number of research studies have been conducted in India on various aspects of priority sector lending by the public and private sector banks. For example, Sooden and Kumar (2007) found that shrinking share of priority sector, neglect of agriculture coupled with its sub-optimum structure and neglect of small scale industries are some serious issues which need immediate attention of the policy makers. Kumar and Gupta 
(2008) observed that agricultural lending by the public sector banks has somewhat stagnated. The percentage share of small scale industries in overall priority sector lending recorded a continuous decline and the percentage share of 'other priority sector' in the overall priority sector lending registered a continuous increase during the period under context. Uppal (2009) observed that whereas, public sector banks have failed to achieve the target of 40 per cent, private sector banks have succeeded in achieving the overall target. Shabbir (2013) found that public and private sector banks are fulfilling the overall priority sector lending target but not able to fulfil the sub target of 18 per cent for agriculture sector. This paper analyses the structure of priority sector lending in India over a period of time starting from 2001 to 2014.

\subsection{Research Methodology}

The main objective of the paper is to analyse the level and structure of priority sector lending in India during the $21^{\text {st }}$ century. The entire study is based upon secondary data and all the required information is collected from the various relevant issues published by the Reserve Bank of India. Further, the period is sub-divided in to two parts i.e. Period I which includes the years 2001 to 2007 and Period II stretching over the years 2008 to 2014.

With a view to analyse the growth of priority sector lending, exponential growth rate has been calculated as follows:

$\mathrm{Yi}=\mathrm{a}_{0} * \mathrm{~b}_{\mathrm{i}}^{\mathrm{t}}$

$\ln \left(\mathrm{Y}_{\mathrm{i}}\right)=\ln \left(\mathrm{a}_{0}\right)+\mathrm{t}^{*} \ln \left(\mathrm{b}_{\mathrm{i}}\right)$

$\mathrm{g}=(\mathrm{b}-1)$, where: $\mathrm{Y}_{\mathrm{i}}$ is the value of ith indicator, $\mathrm{a}=$ constant, $\mathrm{b}_{\mathrm{i}}=$ regression coefficient of ith indicator, $t=$ time period, $\ln =$ common $\log$ value, $g=$ growth rate.

The structure of priority sector lending is examined by mean value of an indicator which, is calculated separately for first and second phase of the study.

The combined mean $(X)=\frac{\mathrm{n} 1 \mathrm{X} 1+\mathrm{n} 2 \mathrm{X} 2+\mathrm{n} 3 \mathrm{X} 3+\cdots \ldots \ldots \ldots \mathrm{n} \mathrm{n} X \mathrm{n}}{\mathrm{n} 1+\mathrm{n} 2+\mathrm{n} 3+\cdots \ldots \ldots \ldots . \mathrm{n}}$

$$
\mathrm{Xi}=\frac{\sum_{i=1}^{n} \mathrm{nixi}}{\sum_{i=1}^{n} \mathrm{ni}} \mathrm{i}=1
$$

Where, $\mathrm{n}_{\mathrm{i}}$ stands for number of observations and $\mathrm{X}_{\mathrm{i}}$ stands for mean value.

The behavior of inter-sector disparities in priority sector lending is explained with the help of co-efficient of variation (C.V.). The value of C.V. is ascertained as follows:

$$
\begin{aligned}
\text { C.V. } & =\frac{\sigma i}{X i} \times 100 \quad \text { Where, C.V. stands for co-efficient of variation, } \\
\sigma_{\mathrm{i}} & =\text { Standard deviation of ith indicator, } X_{\mathrm{i}}=\text { Mean value of ith indicator. }
\end{aligned}
$$


The performance of public and private sector banks in priority sector lending during the first and second phase of the study will be compared with t-test. The value of t-test will be computed as follow:

$$
\mathrm{t}=\frac{X 1-X 2}{S} \sqrt{\frac{n 1 n 2}{n 1+n 2}}
$$

where, $n 1$ and $n 2=$ size of two independent samples i.e. no. of years; $X_{1}$ and $X_{2}$ is the mean value i.e. mean value of priority sector lending by public and private sector banks. $\mathrm{S}=$ combined standard deviation of two samples i.e. priority sector lending. The null hypothesis is tested at $5 \%$ and $1 \%$ level of significance.

\subsection{Priority Sector Lending by Public and Private Sector Banks}

The priority sector credit by public sector banks, on an average, increased at a rate of 23.80 per cent during the first phase and this rate declined to 16.85 per cent during the second phase of the study (Table 1). The public sector banks, on an average, deployed 42.24 per cent of NBC in priority sector during the first phase. It was observed that in all the years (except 2007) of the first phase the prescribed target of priority sector lending was achieved by public sector banks. The analysis revealed further that the prescribed target of priority sector lending was also achieved during the second phase and on an average, 40.48 per cent of NBC was deployed in priority sector by public sector banks.

Further, the priority sector credit by the private sector banks, on an average, increased at a high rate of 38.81 per cent during the first phase and this rate declined by a big margin to 17.47 per cent during the second phase of the study (Table 1). The private sector banks, on an average, deployed 42.85 per cent of NBC in priority sector during the first phase. The analysis revealed that in all the years (except 2001) of the first phase the prescribed target of priority sector lending was achieved. During the second phase, the prescribed target of priority sector lending was also achieved (except the years 2012 and 2013) by private sector banks. During this phase, public sector banks, on an average, deployed 43.96 per cent of NBC in priority sector.

\subsection{Sector-wise deployment of priority sector lending by public sector banks}

Agriculture credit, on an average, recorded a rate of growth of 25.68 per cent during the first period, which declined to 17.50 per cent in the second phase (Table 2). So, study, due to new policy guidelines issued in 1991 under the umbrella of financial sector reforms. Under the new policy guidelines of 1991, the public sector banks in default in meeting the priority sector sub-target of 18 per cent of net bank credit to 
agriculture would compensate the deficiency by contributing to Rural Infrastructure Development Fund (RIDF) and to the consortium fund of Khadi and Village industries Commission (KVC). In this way the banks could move away from their responsibility of direct lending to priority sectors especially the risky venture like agriculture.

Table 1: Credit Deployed to the Priority Sector

(Amount in ₹ Crore)

\begin{tabular}{|c|c|c|c|c|c|c|}
\hline \multirow[t]{2}{*}{ Years } & \multicolumn{3}{|c|}{ Public Sector Banks } & \multicolumn{3}{|c|}{ Private Sector Banks } \\
\hline & NBC & $\begin{array}{l}\text { Total } \\
\text { PSAs }\end{array}$ & $\begin{array}{c}\text { \%age to } \\
\text { NBC }\end{array}$ & NBC & $\begin{array}{l}\text { Total } \\
\text { PSAs }\end{array}$ & $\begin{array}{c}\text { \%age to } \\
\text { NBC }\end{array}$ \\
\hline \multicolumn{7}{|l|}{ Period I } \\
\hline 2001 & 340888 & 146546 & 42.99 & 56410 & 21549 & 38.20 \\
\hline 2002 & 396954 & 171185 & 43.12 & 63012 & 25709 & 40.80 \\
\hline 2003 & 477899 & 203095 & 42.50 & 82669 & 36705 & 44.40 \\
\hline 2004 & 558849 & 245672 & 43.96 & 111521 & 52861 & 47.40 \\
\hline 2005 & 717304 & 310093 & 43.23 & 160289 & 69886 & 43.60 \\
\hline 2006 & 1017614 & 410379 & 40.33 & 248986 & 106566 & 42.80 \\
\hline 2007 & 1317705 & 521180 & 39.55 & 336693 & 143768 & 42.70 \\
\hline Average & 689602 & 286879 & 42.24 & 142797 & 65292 & 42.85 \\
\hline GR in \% & 25.43 & 23.80 & & 36.78 & 38.81 & \\
\hline C.V. in \% & & & 3.89 & & & 6.71 \\
\hline \multicolumn{7}{|l|}{ Period II } \\
\hline 2008 & 1364268 & 608963 & 44.64 & 343627 & 163223 & 47.50 \\
\hline 2009 & 1693437 & 720083 & 42.52 & 406425 & 190207 & 46.80 \\
\hline 2010 & 2073290 & 864562 & 41.70 & 468589 & 215551 & 46.00 \\
\hline 2011 & 2490593 & 1028615 & 41.30 & 533966 & 248828 & 46.60 \\
\hline 2012 & 3021364 & 1129990 & 37.40 & 726954 & 286420 & 39.40 \\
\hline 2013 & 3529890 & 1284880 & 36.40 & 872845 & 327317 & 37.50 \\
\hline 2014 & 4109063 & 1618971 & 39.40 & 1057986 & 464456 & 43.90 \\
\hline Average & 261170 & 1036581 & 40.48 & 630056 & 270857 & 43.96 \\
\hline GR in \% & 20.21 & 16.85 & & 21.02 & 17.47 & \\
\hline C.V. in \% & & & 7.20 & & & 9.02 \\
\hline
\end{tabular}

Source: Complied on the basis of Relevant Issues of 'Report on Trend and Progress of Banking in India' and Statistical Tables Relating to Banks in India', Published by RBI.

As per the Reserve Bank of India norms, public sector banks are required to lend 18 per cent of net bank credit to agriculture sector since the year 1990 onwards. The public sector banks, on an average, deployed 15.16 per cent of net bank credit in agriculture sector and failed to achieve the stipulated target of 18 per cent of NBC during the first phase. Further, in none of the years of the second phase (except the year 2008), the prescribed target of agricultural lending was achieved. The public sector banks, on an average, deployed 16.93 per cent of net bank credit in agriculture sector. 
22 |MUDRA: Journal of Finance and Accounting, Volume 3, Issue 2

Table 2: Sectoral Deployment of Priority Sector Credit by Public Sector Banks

(Amount in Rs. Crores)

\begin{tabular}{|c|c|c|c|c|c|c|c|c|c|}
\hline \multirow{2}{*}{ Year } & \multicolumn{3}{|c|}{ Agriculture } & \multicolumn{3}{c|}{ SSIs } & \multicolumn{2}{c|}{ 'Other Priority Sector' } \\
\cline { 2 - 10 } & Credit & $\begin{array}{c}\text { \% to } \\
\text { TPSAs }\end{array}$ & $\begin{array}{c}\text { \%to } \\
\text { NBC }\end{array}$ & Credit & $\begin{array}{c}\text { \% to } \\
\text { TPSAs }\end{array}$ & $\begin{array}{c}\text { \% to } \\
\text { NBC }\end{array}$ & Credit & $\begin{array}{c}\text { \% to } \\
\text { TPSAs }\end{array}$ & $\begin{array}{c}\text { \% to } \\
\text { NBC }\end{array}$ \\
\hline Period-I & & & & & & & & & \\
\hline 2001 & 53571 & 36.55 & 15.71 & 48400 & 33.02 & 14.20 & 40791 & 27.83 & 11.97 \\
\hline 2002 & 58142 & 33.96 & 14.64 & 54268 & 31.70 & 13.67 & 59074 & 34.50 & 14.88 \\
\hline 2003 & 70501 & 34.71 & 14.75 & 52646 & 26.92 & 11.02 & 76638 & 37.73 & 16.03 \\
\hline 2004 & 84435 & 34.36 & 15.10 & 58311 & 23.73 & 10.43 & 101710 & 41.40 & 18.19 \\
\hline 2005 & 109917 & 35.44 & 15.32 & 67800 & 21.86 & 9.45 & 125114 & 40.34 & 17.44 \\
\hline 2006 & 155220 & 37.82 & 15.25 & 82434 & 20.08 & 8.10 & 163756 & 39.90 & 16.09 \\
\hline 2007 & 202614 & 38.87 & 15.37 & 102550 & 19.67 & 7.78 & 206661 & 39.65 & 15.68 \\
\hline Average & $\mathbf{1 0 4 9 1 4}$ & $\mathbf{3 5 . 9 6}$ & $\mathbf{1 5 . 1 6}$ & $\mathbf{6 6 6 3 0}$ & $\mathbf{2 5 . 2 8}$ & $\mathbf{1 0 . 6 6}$ & $\mathbf{1 1 0 5 3 5}$ & $\mathbf{3 7 . 3 4}$ & $\mathbf{1 5 . 7 5}$ \\
\hline GR in \% & $\mathbf{2 5 . 6 8}$ & & & $\mathbf{1 2 . 6 8}$ & & & $\mathbf{3 0 . 2 4}$ & & \\
\hline C.V. in \% & & $\mathbf{5 . 1 6}$ & $\mathbf{2 . 4 4}$ & & $\mathbf{2 1 . 4 5}$ & $\mathbf{2 3 . 6 3}$ & & $\mathbf{1 2 . 7 5}$ & $\mathbf{1 2 . 7 1}$ \\
\hline Period-II & & & & & & & & & \\
\hline 2008 & 249397 & 40.95 & 18.28 & 151137 & 24.76 & 11.08 & 209842 & 34.38 & 15.38 \\
\hline 2009 & 298211 & 41.41 & 17.61 & 191307 & 26.57 & 11.30 & 230507 & 32.01 & 13.61 \\
\hline 2010 & 372463 & 43.08 & 17.96 & 276319 & 31.96 & 13.33 & 214996 & 24.86 & 10.37 \\
\hline 2011 & 414973 & 40.34 & 16.66 & 369430 & 35.91 & 14.83 & 237092 & 23.05 & 9.52 \\
\hline 2012 & 479400 & 42.43 & 15.87 & 396993 & 35.13 & 13.14 & 247755 & 21.93 & 8.20 \\
\hline 2013 & 531701 & 41.38 & 15.06 & 478361 & 37.23 & 13.55 & 273349 & 21.27 & 7.74 \\
\hline 2014 & 702541 & 43.39 & 17.09 & 593410 & 36.65 & 14.44 & 306956 & 18.96 & 7.47 \\
\hline Average & $\mathbf{4 3 5 5 2 7}$ & $\mathbf{4 1 . 8 5}$ & $\mathbf{1 6 . 9 3}$ & $\mathbf{3 5 0 9 9 4}$ & $\mathbf{3 2 . 6 0}$ & $\mathbf{1 3 . 1 0}$ & $\mathbf{2 4 5 7 8 5}$ & $\mathbf{2 5 . 2 1}$ & $\mathbf{1 0 . 3 3}$ \\
\hline GR in \% & $\mathbf{1 7 . 5 0}$ & & & $\mathbf{2 5 . 2 3}$ & & & $\mathbf{5 . 9 8}$ & & \\
\hline C.V. in \% & & $\mathbf{2 . 7 1}$ & $\mathbf{6 . 8 5}$ & & $\mathbf{1 5 . 5 1}$ & $\mathbf{1 0 . 9 6}$ & & $\mathbf{2 2 . 9 3}$ & $\mathbf{2 9 . 6 7}$ \\
\hline Source: Sa & & & & & & &
\end{tabular}

Source: Same as Table 1

An analysis of rate of growth of credit to SSIs revealed that it, on an average, increased at a rate of 12.68 per cent during the first phase, but, rose at a higher rate of 25.23 per cent during the second phase. However, the public sector banks, on an average, deployed 10.66 per cent of net bank credit to SSIs during the first phase. This share rose marginally to 13.10 per cent during the second phase, in the absence of any clear guidelines by RBI (as it is there in case of agriculture). It was so because, despite the fact that the public sector banks together have gradually increased the quantum of advances to small scale industries, but, the proportion in which net bank credit in priority sector has expanded, the relative share of small sector has not grown in the same ratio during the period of study.

The public sector banks 'other priority sector' credit, on an average, increased at a high rate of 30.24 per cent during the first phase (Table 2). However, this rate declined 
and stood at 5.98 per cent per annum during the second phase. The public sector banks, on an average, deployed 15.75 per cent and 10.33 per cent of net bank credit in 'other priority sector' during the first and second of the study respectively in the absence of any clear guidelines by RBI.

\subsection{Sector-wise deployment of priority sector lending by private sector banks}

Agriculture credit, on an average, recorded a higher rate of growth of 45.45 per cent during the first period and this rate declined to 13.98 per cent in the second phase. The private sector banks as per the Reserve Bank of India norms are also required to lend 18 per cent of net bank credit to agriculture sector. These banks, on an average, deployed 12.01 per cent of net bank credit in agriculture sector and thus failed to achieve the stipulated target of lending in the first phase. During the second phase, in none of the years (except the year 2010), the prescribed target lending was achieved and private sector banks, on an average, deployed 15.56 per cent of net bank credit in agriculture sector.

An analysis of rate of growth of credit to SSIs revealed that it, on an average, recorded a moderate rate of growth of 7.04 per cent during the first phase, but, rose at a higher rate of 28.22 per cent during the second phase (Table 3). The private sector banks, on an average, deployed 8.29 per cent of net bank credit to SSIs during the first phase. However, this share rose marginally to 15.11 per cent during the second phase. An analysis of rate of growth of credit to 'other priority sector' revealed that it, on an average, stood as high as 50.96 per cent in the first phase. However, this rate declined to 9.96 per cent per during the second phase of the study. The percentage share of 'other priority sector' credit to net bank credit, on an average, stood at 20.63 and 12.69 per cent of during the first and second phase respectively.

\subsection{Results and Discussion}

\subsection{Test of hypothesis of mean value of credit deployed to priority sector by the two bank groups}

The null hypothesis states that there is no significant difference in the mean value of credit deployed by two bank groups $\left(H_{0}: \mu_{1}=\mu_{2}\right)$; whereas, the alternative hypothesis states that there is significant difference in the mean value of credit deployed by two bank groups $\left(H_{1}: \mu_{1} \neq \mu_{2}\right)$. Since, the calculated value of t-test during the first phase and second phase are 3.39 and 4.80 respectively (Table 4 ), which are more than the table value (for $v=12, t_{0.05}=2.17$ ) and are found significant at $1 \%$ and $5 \%$ level (significance, two tailed test $=0.000$ and 0.000 ), so the null hypothesis is rejected and 
24 | MUDRA: Journal of Finance and Accounting, Volume 3, Issue 2

alternative hypothesis is accepted, and we conclude that there is significant difference in the mean value of credit deployed by public and private sector bank groups $\left(H_{1}: \mu_{1} \neq \mu_{2}\right)$ during the first and second phase of the study.

Table 3: Sectoral Deployment of Priority Sector Credit by Private Sector Banks

(Amount in ₹ Crores)

\begin{tabular}{|c|c|c|c|c|c|c|c|c|c|}
\hline \multirow{2}{*}{ Year } & \multicolumn{3}{|c|}{ Agriculture } & \multicolumn{3}{c|}{ SSIs } & \multicolumn{2}{c|}{ 'Other Priority Sector' } \\
\cline { 2 - 10 } & Credit & $\begin{array}{c}\text { \% to } \\
\text { TPSAs }\end{array}$ & $\begin{array}{c}\text { \% to } \\
\text { NBC }\end{array}$ & Credit & $\begin{array}{c}\text { \% to } \\
\text { TPSAs }\end{array}$ & $\begin{array}{c}\text { \% to } \\
\text { NBC }\end{array}$ & Credit & $\begin{array}{c}\text { \% to } \\
\text { TPSAs }\end{array}$ & $\begin{array}{c}\text { \% to } \\
\text { NBC }\end{array}$ \\
\hline Period-I & & & & & & & & & \\
\hline 2001 & 5634 & 26.12 & 9.60 & 8096 & 37.54 & 13.80 & 7219 & 33.47 & 12.30 \\
\hline 2002 & 8022 & 31.20 & 8.50 & 8613 & 33.50 & 13.70 & 9074 & 35.30 & 14.40 \\
\hline 2003 & 9924 & 27.08 & 12.00 & 8051 & 21.97 & 9.70 & 18673 & 50.95 & 22.50 \\
\hline 2004 & 14730 & 30.11 & 14.20 & 7590 & 15.52 & 7.30 & 25786 & 52.71 & 24.90 \\
\hline 2005 & 21636 & 30.96 & 13.50 & 8592 & 12.29 & 5.40 & 38797 & 55.51 & 24.20 \\
\hline 2006 & 36712 & 34.44 & 13.60 & 10421 & 9.78 & 4.20 & 57777 & 54.20 & 23.20 \\
\hline 2007 & 52034 & 36.00 & 12.70 & 13136 & 9.09 & 3.90 & 76919 & 53.21 & 22.90 \\
\hline Average & $\mathbf{2 1 2 4 2}$ & $\mathbf{3 0 . 8 4}$ & $\mathbf{1 2 . 0 1}$ & $\mathbf{9 2 1 4}$ & $\mathbf{1 9 . 9 6}$ & $\mathbf{8 . 2 9}$ & $\mathbf{3 3 4 6 4}$ & $\mathbf{4 7 . 9 1}$ & $\mathbf{2 0 . 6 3}$ \\
\hline GR in \% & $\mathbf{4 5 . 4 5}$ & & & $\mathbf{7 . 0 4}$ & & & $\mathbf{5 0 . 9 6}$ & & \\
\hline C.V. in \% & & $\mathbf{1 1 . 5 9}$ & $\mathbf{1 8 . 0 9}$ & & $\mathbf{5 7 . 7 5}$ & $\mathbf{5 0 . 9 5}$ & & $\mathbf{1 9 . 5 3}$ & $\mathbf{2 4 . 5 9}$ \\
\hline Period-II & & & & & & & & & \\
\hline 2008 & 58567 & 35.70 & 15.40 & 46912 & 28.60 & 13.70 & 58556 & 35.70 & 17.00 \\
\hline 2009 & 76062 & 39.99 & 15.90 & 47916 & 25.19 & 12.00 & 66197 & 34.80 & 16.30 \\
\hline 2010 & 90737 & 42.09 & 19.36 & 64825 & 30.07 & 13.83 & 59107 & 27.42 & 12.61 \\
\hline 2011 & 92136 & 37.03 & 17.26 & 87857 & 35.31 & 16.45 & 68835 & 27.66 & 12.89 \\
\hline 2012 & 104200 & 36.38 & 14.33 & 110500 & 38.58 & 15.20 & 71700 & 25.03 & 9.86 \\
\hline 2013 & 111900 & 34.19 & 12.82 & 141700 & 43.29 & 16.23 & 73800 & 22.54 & 8.46 \\
\hline 2014 & 146687 & 31.58 & 13.86 & 193900 & 41.74 & 18.33 & 123869 & 26.67 & 11.70 \\
\hline Average & $\mathbf{9 7 1 8 4}$ & $\mathbf{3 6 . 7 1}$ & $\mathbf{1 5 . 5 6}$ & $\mathbf{9 9 0 8 7}$ & $\mathbf{3 4 . 6 8}$ & $\mathbf{1 5 . 1 1}$ & $\mathbf{7 4 5 8 1}$ & $\mathbf{2 8 . 5 5}$ & $\mathbf{1 2 . 6 9}$ \\
\hline GR in \% & $\mathbf{1 3 . 9 8}$ & & & $\mathbf{2 8 . 2 2}$ & & & $\mathbf{9 . 9 6}$ & & \\
\hline C.V. in \% & & $\mathbf{9 . 5 4}$ & $\mathbf{1 4 . 2 2}$ & & $\mathbf{1 9 . 9 7}$ & $\mathbf{1 3 . 9 7}$ & & $\mathbf{1 7 . 1 8}$ & $\mathbf{2 4 . 6 2}$ \\
\hline Source: & & & & & & &
\end{tabular}

Source: Same as Table 1

Table 4: t-test of Credit Deployed to Priority Sector by Two Bank Groups

\begin{tabular}{|c|c|c|c|c|c|}
\hline Period I & Mean Value & Std. Dev. & t-test & d. f. (v) & Sig. (2-Tailed Test) \\
\hline Public Sector Banks & 11475.14 & 5476.84 & 3.39 & 12 & 0.000 \\
\hline Private Sector Banks & 3840.71 & 2667.15 & & & \\
\hline Period II & Mean Value & Std. Dev. & t-test & d. f. (v) & Sig. (2-Tailed Test) \\
\hline Public Sector Banks & 41463.22 & 13877.92 & 4.80 & 12 & 0.000 \\
\hline Private Sector Banks & 15932.79 & 6005.77 & & & \\
\cline { 1 - 3 }
\end{tabular}

Note: $n_{1}=7$ and $n_{2}=7$ (Number of years). Degrees of freedom, $d . f .(v)=n_{1}+n_{2}-2=7+7-2=12$.

The value of $t$-test for two tailed test for $v=12$ is $\left(t_{0.05}\right)=2.17$. 


\subsection{Test of Hypothesis of Mean Value of Credit Deployed to Various Components of Priority Sector by Two Bank Groups:}

The null hypothesis states that there is no significant difference in the mean value of credit deployed to agriculture sector by two bank groups $\left(H_{0}: \mu_{1}=\mu_{2}\right)$. Whereas, the alternative hypothesis states that there is significant difference in the mean value of credit deployed by two bank groups $\left(H_{1}: \mu_{1} \neq \mu_{2}\right)$. Since, the calculated value of t-test during the first and second phase are 3.40 and 5.64 respectively (Table 5), which are more than the table value (for $v=12, t_{0.05}=2.17$ ) and are found significant at $1 \%$ and $5 \%$ level (significance, two tailed test $=0.008$ and 0.000 ), so the null hypothesis is rejected and alternative hypothesis is accepted, and we conclude that there is significant difference in the mean value of credit deployed to agriculture sector by public and private sector bank groups $\left(H_{1}: \mu_{1} \neq \mu_{2}\right)$ during the both the phases of the study.

Table 5: t-test of Credit Deployed to Agriculture, SSIs and 'Other Priority Sector' by Two Bank Groups

\begin{tabular}{|c|c|c|c|c|c|}
\hline \multicolumn{6}{|c|}{ Agriculture Credit } \\
\hline Period I & Mean Value & Std. Dev. & t-test & d. f. (v) & Sig. (2-Tailed Test) \\
\hline Public Sector Banks & 4196.57 & 2222.81 & \multirow[t]{2}{*}{3.40} & \multirow[t]{2}{*}{12} & \multirow[t]{2}{*}{0.008} \\
\hline Private Sector Banks & 1249.51 & 1012.18 & & & \\
\hline Period II & Mean Value & Std. Dev. & t-test & d. f. (v) & Sig. (2-Tailed Test) \\
\hline Public Sector Banks & 17421.06 & 6118.18 & \multirow[t]{2}{*}{5.64} & \multirow[t]{2}{*}{12} & \multirow[t]{2}{*}{0.000} \\
\hline Private Sector Banks & 5716.71 & 1650.00 & & & \\
\hline \multicolumn{6}{|c|}{ Small Scale Industries (SSIs) Credit } \\
\hline Period I & Mean Value & Std. Dev. & t-test & d. f. (v) & Sig. (2-Tailed Test) \\
\hline Public Sector Banks & 2665.19 & 19541.80 & \multirow[t]{2}{*}{0.19} & \multirow[t]{2}{*}{12} & \multirow[t]{2}{*}{1.230} \\
\hline Private Sector Banks & 542.01 & 1950.51 & & & \\
\hline Period II & Mean Value & Std. Dev. & t-test & d. f. (v) & Sig. (2-Tailed Test) \\
\hline Public Sector Banks & 14039.75 & 6292.06 & \multirow[t]{2}{*}{7.84} & \multirow[t]{2}{*}{12} & \multirow[t]{2}{*}{0.010} \\
\hline Private Sector Banks & 5828.66 & 3183.75 & & & \\
\hline \multicolumn{6}{|c|}{ 'Other Priority Sector' Credit } \\
\hline Period I & Mean Value & Std. Dev. & t-test & d. f. (v) & Sig. (2-Tailed Test) \\
\hline Public Sector Banks & 4421.39 & 2367.82 & \multirow[t]{2}{*}{2.35} & \multirow[t]{2}{*}{12} & \multirow[t]{2}{*}{0.040} \\
\hline Private Sector Banks & 1968.45 & 1531.92 & & & \\
\hline Period II & Mean Value & Std. Dev. & t-test & d. f. (v) & Sig. (2-Tailed Test) \\
\hline Public Sector Banks & 9831.41 & 1371.56 & \multirow[t]{2}{*}{7.55} & \multirow[t]{2}{*}{12} & \multirow[t]{2}{*}{6.702} \\
\hline Private Sector Banks & 4387.09 & 1323.59 & & & \\
\hline
\end{tabular}

Note: Same as Table 4 
In case of SSIs, the calculated value of t-test during the first phase is 0.19 , which is less than the table value ( $f \circ r v=12, t_{0.05}=2.17$ ) and it is found insignificant at $1 \%$ and $5 \%$ level (significance, two tailed test=1.230), so the null hypothesis is accepted and alternative hypothesis is rejected, and we conclude that there is no significant difference in the mean value of credit deployed to SSIs by public and private sector bank groups $\left(H_{1}: \mu=\mu_{2}\right)$ during the first phase. However, during the second phase, the calculated value of t-test is 7.84, which is more than the table value (for $v=12, t_{0.05}=2.17$ ) and it is also found significant at $1 \%$ and $5 \%$ level (Significance, two tailed test $=0.010$ ), so the null hypothesis is rejected and alternative hypothesis is accepted, and we conclude that there is significant difference in the mean value of credit deployed to SSIs by public and private sector bank groups $\left(H_{1}: \mu_{1} \neq \mu_{2}\right)$ during the second phase first phase of the study.

Further, in case of 'Other Priority Sector', the calculated value of t-test during the first and phase are 2.35 and 7.55 respectively (Table 5), which are more than the table value (for $v=12, t_{0.05}=2.17$ ) and are found significant at $1 \%$ and $5 \%$ level (significance, two tailed test $=0.040$ and 0.000 ), so the null hypothesis is rejected and alternative hypothesis is accepted, and we conclude that there is significant difference in the mean value of credit deployed to 'Other Priority Sector' by public and private sector bank groups $\left(H_{1}: \mu_{1} \neq \mu_{2}\right)$ during the first and phase.

\subsection{Conclusion and Policy Implications}

It was observed that the priority sector lending by private sector banks registered a higher rate of growth vis-à-vis public sector banks, during both the phases of the study. From the analysis it was found that, on an average, the prescribed target of priority sector lending was achieved by public as well as private sector banks during the first and second phase. Although, on an average, the prescribed target of lending has been achieved, but, one important issue of concern is the shrinking share of priority sector credit in net bank credit over a period of time by both the public and private sector banks, which needs immediate attention of the policy makers. The inter-year disparities in priority sector lending in case of private sector banks are found to be higher as compared to public sector banks in both the phases. The public and private sector banks, on an average, could not deploy 18 per cent of net bank credit in agriculture sector and thus, failed to achieve the stipulated target of agricultural lending during the first as well as second phase. It was found that, within the priority sector, the share of agriculture and SSIs credit has increased while, that of 'other priority sector' by both the bank groups has decreased during the period under study. 
Financial inclusion and priority sector credit are closely interconnected subjects as financial inclusion is the process and priority sector loans are the business effect/ end product of the same in the books of the banks. If we are doing financial inclusion, then these targets are achievable, if not, then these are not. We need to be consistent in our approach towards financial inclusion and priority sector lending. Any attempt to strengthen the priority sector lending is essentially a small step in a long journey of financial inclusion. This means that expanding financial inclusion requires, among other things, a paradigm shift that goes beyond opening bank accounts and facilitating direct cash transfers to the financial excluded. The banking sector, especially public sector banks, should lead efforts to expand inclusion as private sector initiatives to do so are likely to be curtailed by their objective of maximising shareholder profit rather than optimising stakeholder value.

\section{References}

Agarwal, O.P. (2008). Modern Banking of India. Himalaya Publishing House: New Delhi.

Desai, V. (2009). The Indian Financial System and Development. Himalaya Publishing House: New Delhi.

Gupta, S.P. (2000). Statistical Methods. Sultan Chand and Sons: New Delhi.

Kumar, S. \& Gupta, Y. (2008). A comparative study of priority sector lending in India by public and private sector banks. The Indian Journal of Economics, 89 (353-II):193204.

Mujumdar, N. A. (1998). Credit support to priority sector- A macro perspective. Economic and Political Weekly, 24:147-150.

Mukherjee D. D. (2014). Credit Appraisal, Risk Analysis \& Decision Making - An Integrated Approach to on and off Balance Sheet Lending. Snow White Publications Pvt. Ltd.: Mumbai.

Parimalarani, G. (2011). Performance of commercial banks in priority sector lending. Asia Pacific Journal of Research in Business Management, 2 (7): 221- 230. 
28 | MUDRA: Journal of Finance and Accounting, Volume 3, Issue 2

Ravichandran, K. (2008). Merchant Banking and Financial Services. Himalaya Publishing House: New Delhi.

Satish, P. (2007). Agricultural Credit in the Post-Reform Era-A Target of Systematic Policy Correction. Economic and Political Weekly, 30:2567-2575.

Shabbir, N. (2013). Region-wise priority sector advances in India. Journal of Social Science for Policy Implications, 1 (2).

Shajahan, K.M. (1998). Priority sector bank lending- Some important issues. Economic and Political Weekly, 22(42 \&43): 2749-2756.

Shete, N.B. (2002-03). Priority Sector advances of banks during the post-reform period. Prajnan, 31(1):21-37.

Sooden, M. \& Kumar, S. (2007). Priority Sector Lending in the Post Reform Period. Finance India, 21(4):1389-1404.

Uppal, R.K. (2009). Priority sector advances: Trends, issues and strategies. Journal of Accounting and Taxation, 1(5): 079-089.

Veerakumar, K. (2012). Non-performing assets in priority sector: A threat to Indian Scheduled commercial banks. International Research Journal of Finance and Economics, 93: 6-23.

Vijayaragavan, G. (2009). Bank Credit Management. Himalaya Publishing House: New Delhi. 